\title{
Inhibitory Effect of Moriniafungin Produced by Setosphaeria rostrata F3736 on the Development of Rhizopus Rot
}

\author{
Min Young Park ${ }^{1}$, So Jung Park², Jae-Jin Kim³, Dong Ho Lee ${ }^{1,4}$, and Beom Seok Kim ${ }^{\text {1,4* }}$ \\ ${ }^{1}$ Department of Biosystems and Biotechnology, Korea University Graduate School, Seoul 02841, Korea \\ ${ }^{2}$ Food-Biotech Research, LOTTE R\&D Center, Seoul 07594, Korea \\ ${ }^{3}$ Division of Environmental Science and Ecological Engineering, College of Life Science and Biotechnology, Korea \\ University, Seoul 02841, Korea \\ ${ }^{4}$ Division of Biotechnology, College of Life Sciences and Biotechnology, Korea University, Seoul 02841, Korea
}

(Received on September 9, 2020; Revised on October 26, 2020; Accepted on November 9, 2020)

Rhizopus rot is a serious postharvest disease of various crops caused by Rhizopus spp. and controlled mainly by synthetic fungicides. We detected the antifungal activity of a culture extract of Setosphaeria rostrata F3736 against Rhizopus oryzae. The active ingredient was identified as moriniafungin, a known sordarin derivative, which showed minimum inhibitory concentrations of $1-8 \mu \mathrm{g} / \mathrm{ml}$ against Colletotrichum spp. and 0.03-0.13 $\mu \mathrm{g} / \mathrm{ml}$ against Rhizopus spp. in vitro. Moriniafungin showed protective control efficacies against Rhizopus rot on apple and peach fruits. Treatment with $25 \mu \mathrm{g} /$ $\mathrm{ml}$ moriniafungin delimited the lesion diameter significantly by $100 \%$ on $R$. oryzae-inoculated apple fruits compared with the non-treated control. Treatment with $0.04 \mu \mathrm{g} / \mathrm{ml}$ of moriniafungin reduced the lesion diameter significantly by $\mathbf{5 6 . 4 5 \%}$, and treatment with higher concentrations of $0.2-25 \mu \mathrm{g} / \mathrm{ml}$ reduced the lesion diameter by $\mathbf{7 0 - 9 0 \%}$ on Rhizopus stolonifer var. stoloniferinoculated peach fruit. These results suggest moriniafungin has potential as a control agent of postharvest diseases caused by Rhizopus spp.

Keywords : fungal metabolite, moriniafungin, postharvest disease, Rhizopus rot, Setosphaeria rostrata

\footnotetext{
*Corresponding author.

Phone) +82-2-3290-3047, FAX) +82-2-921-1715

E-mail) biskim@korea.ac.kr

(c) This is an Open Access article distributed under the terms of the Creative Commons Attribution Non-Commercial License (http:// creativecommons.org/licenses/by-nc/4.0) which permits unrestricted noncommercial use, distribution, and reproduction in any medium, provided the original work is properly cited.
}

Articles can be freely viewed online at www.ppjonline.org.
Handling Editor : Yong Hoon Lee

In maintaining a consistent yield and quality of agricultural products, synthetic fungicides have played an important role through efficient control of plant diseases. However, safety and environmental problems caused by excessive use of synthetic fungicides instituted strict regulations on the registration of the active ingredients and application rates in fields (Paster and Bullerman, 1988). As an alternative to synthetic agents, microbial natural products have been considered as a source of diverse antifungal agents for plant disease control. Microbial natural products have been regarded as environment-friendly because their biodegradability could solve the residual problem of synthetic fungicides (Porter, 1985). Furthermore, owing to their versatile biological activity and structural diversity, microbial metabolites microbial metabolites are expected to provide new modes of action that would be effective against phytopathogenic fungi resistant to commercial fungicides (Kim and Hwang, 2007).

Among the fungal metabolites discovered so far, strobilurin A and B, isolated from the basidiomycete Strobilurus tenacellus, and several structurally-related compounds are the most famous fungal metabolites (Anke et al., 1977). Structural modification to improve the photostability and bioactivity of natural strobilurin enabled the commercialization of several strobilurin derivatives, such as azoxystrobin, pyraclostrobin, and kresoxim-methyl, as agricultural fungicides (Bartlett et al., 2002). Strobilurin binds to the ubihydroquinone oxidation center of the $b c_{1}$ complex, which blocks electron transfer between cytochrome $b$ and 
cl in the mitochondrial membrane, thereby disturbing respiration and providing potent, broad-spectrum disease control efficacy at a parts-per-billion concentration (Bartlett et al., 2002; Clough et al., 1995; Kim and Hwang, 2007).

Trichoderma strains are one of the most studied fungal biocontrol agents and commercially available as biopesticides and biofertilizers (Harman et al., 2004). Various antibiotic compounds, including volatile and nonvolatile secondary metabolites, are produced by these strains. For instance, the volatile compound 6-pentyl-2H-pyran-2-one, exhibited in vivo and in vitro antifungal activity against plant fungal pathogens Rhizoctonia solani and Fusarium oxysporum f. sp. lycopersici (Scarselletti and Faull, 1994). Anthraquinone derivatives, including chrysophanol and pachybasin from Trichoderma harzianum, were also suggested to be involved in controlling $R$. solani (Liu et al., 2007).

Rhizopus soft rot disease caused by Rhizopus sp. is one of the most devastating postharvest diseases of various crops, including potato, stone fruits, and berries (Amadioha, 2001; Dennis, 1983; Qing and Shiping, 2000). Rhizopus species have a wide host range and grow fast in moist conditions (Salem et al., 2016). Rhizopus spores are spread into the air and mainly infect the wound sites of fruits and vegetables, followed by secrete strong cell wall-degrading enzymes to colonize the interior of host cells, resulting in serious economic losses during harvest, storage, and transport of fruits and vegetables (Qing and Shiping, 2000; Salem et al., 2016; Tang et al., 2012).

To reduce the loss in postharvest stages, various synthetic fungicides, such as iprodione, dichloran, fludioxonil, and tebuconazole, are applied (Bautista-Baños et al., 2014; Northover and Zhou, 2002). Due to residual toxicities and visible residues, however, only a few fungicides are approved for control of postharvest diseases (Zhang et al., 2020). Biological control of postharvest diseases of fruits by microbial antagonists has been considered as an alternative and effective strategy for reducing the postharvest loss of crops (Wisniewski and Wilson, 1992). Pichia, Cryptococcus, and numerous other yeast strains proved efficacious in controlling this fungus on stone fruit, strawberry, and tomato (Qing and Shiping, 2000; Roberts, 1990). Trichoderma harzianum has also been reported to control Rhizopus rot on apple and peach (Batta, 2007; El-Katatny and Emam, 2020). However, difficulties in maintaining a consistent application of the biological agent have increased interest in developing their antimicrobial metabolites as an alternative agent (Tripathi and Dubey, 2004; Usall et al., 2016). Pascale et al. (2017) studied the effect of harzianic acid and 6-pentyl- $\alpha$-pyrone isolated from $T$. harzianum and T. atro- viride on grape (Vitis vinifera L.) infected with a powdery mildew fungus Uncinula necator. The foliar spray of these compounds suppressed the development of powdery mildew on grape leaves, as well as improved grape yield by $97 \%$ in terms of weight (Pascale et al., 2017).

In a filamentous fungal culture collection that we constructed, the fungal isolate F3736 was found to produce antifungal metabolites effective to inhibit the growth of Rhizopus oryzae in vitro. In the present study, the active compound was purified from the culture extract of F3736 through various chromatographic procedures and identified by spectroscopic analyses. The in vitro antifungal spectrum of the active compound and its control efficacy on Rhizopus rot of apple and peach fruits was also investigated.

\section{Materials and Methods}

Fungal material. Setosphaeria rostrata F3736 was isolated from a wood debris collected in Gaeun Mountain, Seoul, Republic of Korea, in April 2016, and identified using the sequences of internal transcribed spacer region of rDNA by Korea University Culture Collection (KUC).

Purification of antifungal compound derived from $S$. rostrata F3736. S. rostrata F3736 was cultured on potato dextrose agar (PDA; BD Difco, Franklin Lakes, NJ, USA) medium plates $(3 \mathrm{l})$ at $25^{\circ} \mathrm{C}$ for 7 days and extracted with methanol. The methanol extract was filtered and concentrated to dryness, followed by re-suspended in 31 of distilled water and re-extracted with same volume of ethyl acetate. The ethyl acetate layer was fractionated by Diaion gel column chromatography (Mitsubishi Chemical, Tokyo, Japan). The columns were eluted with a stepwise gradient of aqueous methanol $(0 \%, 20 \%, 40 \%, 60 \%, 80 \%$, and $100 \%$, v/v) and washed by $500 \mathrm{ml}$ acetone. The paper disk ( $8 \mathrm{~mm}$ in diameter; Advantec, Toyo, Japan) diffusion assay was used to assess the antifungal activity of each fraction against $R$. oryzae. The spore-seeded agar medium was generated by addition of $1 \mathrm{~mL}$ of conidial suspension $\left(10^{7}\right.$ conidia/ml) of $R$. oryzae into $100 \mathrm{ml}$ of molten PDA $(0.7 \%$ agar). The paper disk absorbed with each fraction was placed on the spore-seeded agar medium and incubated at $28^{\circ} \mathrm{C}$ for 2 days. The active fractions were combined and further purified using a Varian HPLC system (Agilent Technologies, Santa Clara, CA, USA) equipped with a J'sphere ODS-H80 column $(250 \times 10 \mathrm{~mm}, 4 \mu \mathrm{m}$; YMC Co., Ltd., Kyoto, Japan). Chromatography was performed with a linear gradient of 20-95\% aqueous methanol for 20 $\mathrm{min}$ and then isocratic elution (of $95 \%$ aqueous methanol) for $20 \mathrm{~min}$ at a flow rate of $1 \mathrm{ml} / \mathrm{min}$. The eluates were 
monitored at an absorbance of $230 \mathrm{~nm}$. The fractions were manually collected peak by peak and bioassayed against $R$. oryzae. The antifungal fraction was denoted as compound A.

Structural elucidation of purified bioactive compound. The molecular weight of compound A was determined by electrospray ionization mass spectrometry using an ultraperformance liquid chromatography-quadrupole time-offlight mass spectrometer at the Seoul Branch of the Korean Basic Science Institute. The nuclear magnetic resonance (NMR) spectra of compound A was recorded using a Varian 500-MHz nuclear magnetic resonance spectrometer (Varian, Palo Alto, CA, USA) equipped with a 5-mm AutoX DB probe. The ${ }^{1} \mathrm{H}$ - and ${ }^{13} \mathrm{C}-\mathrm{NMR}$ data along with ${ }^{1} \mathrm{H}-$ ${ }^{1} \mathrm{H}$ correlation spectroscopy, ${ }^{1} \mathrm{H}-{ }^{13} \mathrm{C}$ heteronuclear multiple bond correlation, and ${ }^{1} \mathrm{H}^{13} \mathrm{C}$ heteronuclear single quantum correlation spectra of compound A measured in chloroform- $d$ (Cambridge Isotope Laboratory, Andover, MA, USA). Chemical shifts were referenced to solvent peaks $\left(\delta_{\mathrm{H}} 7.26 \mathrm{ppm}\right.$ and $\left.\delta_{\mathrm{C}} 77.0 \mathrm{ppm}\right)$. Based on the spectroscopic data, the structure of compound A was determined.

Effect of moriniafungin on various plant fungal pathogens. The minimum inhibitory concentration (MIC) values of purified moriniafungin were evaluated against various plant pathogenic fungi using the modified CLSI M38-A method (Espinel-Ingroff et al., 2005). The $25 \mu \mathrm{l}$ of conidial suspension $\left(4 \times 10^{5}\right.$ conidia $\left./ \mathrm{ml}\right)$ of $A$. brassicicola, $A$. oryzae, B. cinerea, C. gloeosporioides, $C$. orbiculare, $F$. oxysporum f. sp. lycopersici, $R$. oryzae, or $R$. stolenifer var. stolonifer, together with $25 \mu \mathrm{l}$ of quadruple-strength potato dextrose broth (PDB; BD Difco) were added to 96-well plates (SPL life Sciences, Pocheon, Korea). Subsequently, moriniafungin was added to each well at final concentrations of $0.01,0.02,0.03,0.06,0.13,0.25,0.50,1,2,4,8$, 16,32 , and $64 \mu \mathrm{g} / \mathrm{ml}$. After $28^{\circ} \mathrm{C}$ incubation for 2 days, MICs of compound A against test fungi were determined by visual observation.

In vivo assessment of Rhizopus rot control efficacies. The protective control efficacies of moriniafungin and tebuconazole (as a positive control) against Rhizopus rot were assessed on peach and apple fruits. Purified moriniafungin and a commercial fungicide tebuconazole were prepared in water containing $0.05 \%$ Tween- $20(\mathrm{v} / \mathrm{v})$ and serially diluted to $0.04,0.20,1,5$, and $25 \mu \mathrm{g} / \mathrm{ml}$. Fruits were purchased from a local market for the experiment. The conidia $\left(1 \times 10^{6}\right.$ conidia/ml $)$ of $R$. stolenifer var. stolenifer and $R$. oryzae were harvested with PDB containing $0.05 \%$
Tween-20 after cultivation for 1 week on PDA. Peach and apple fruits were surface disinfested in $1 \%$ sodium hypochlorite, washed, and wounded (three wounds per fruit) using a sterile blue tip (Axygen Scientific, Inc., Union City, $\mathrm{CA}$, USA). Each solution (5 $\mu \mathrm{l})$ of moriniafungin and tebuconazole were applied to the wound site of peach and apple fruits. After air drying for $1 \mathrm{~h}$, conidial suspensions $(5 \mu \mathrm{l})$ of $R$. stolonifer var. stolonifer and $R$. oryzae were inoculated onto wound sites of peach and apple fruits, respectively. The fruits were placed in a humidified plastic container kept at $28^{\circ} \mathrm{C}$. Four days after inoculation, the lesion diameter (mm) of Rhizopus rot in each fruit was measured. Each treatment was performed in three replicates.

Statistical analysis. Data were expressed as mean \pm standard deviation, and the least significant differences method for multiple comparisons was performed by SAS version 9.4 (SAS Institute, Cary, NC, USA). $P<0.05$ to determine differences between means.

\section{Results and Discussion}

Purification of antifungal compound produced by Setosphaeria rostrate. In this study, the culture extract of $S$. rostrata strain F3736 showed inhibitory activity against $R$. oryzae. The antifungal compound was isolated from the culture extract and was identified as moriniafungin. The methanolic extract of $S$. rostrata was partitioned with ethyl acetate and purified by a series of chromatography steps. The Diaion HP-20 column loaded with the ethyl acetate extract fraction produced $80 \%$ and $100 \% \mathrm{MeOH}$ fractions, which were bioactive against $R$. oryzae. The active fractions were further purified by reverse-phase highperformance liquid chromatography (HPLC) with detection at $230 \mathrm{~nm}$. The peak (denoted as compound A) eluted at the retention time of $14.5 \mathrm{~min}$ showed antifungal activity against $R$. oryzae (Fig. 1). The active peak eluate was collected through a repeated preparative HPLC procedure and lyophilized to white powder $(3.5 \mathrm{mg})$.

Structure elucidation of moriniafungin. Electrospray ionization mass spectra of compound A recorded $m / z$ 689.3537, $[\mathrm{M}-\mathrm{H}]^{-}$(calculated, 689.3540 as $\mathrm{C}_{37} \mathrm{H}_{53} \mathrm{O}_{12}$ ) in negative mode, $\mathrm{m} / \mathrm{z}$ 713.3508, $[\mathrm{M}+\mathrm{Na}]^{+}$(calculated, 713.3513 as $\mathrm{C}_{37} \mathrm{H}_{54} \mathrm{NaO}_{12}$ ) in positive mode (Fig. 2). Based on the MS and NMR experimental data (Fig. 2, Supplementary Figs. 1-5) in comparison with literature data (Basilio et al., 2006; Zhang et al., 2019), the structure of compound A was identified as moriniafungin (Fig. 3). The ${ }^{1} \mathrm{H}$ - and ${ }^{13} \mathrm{C}-\mathrm{NMR}$ data of compound A were summarized 


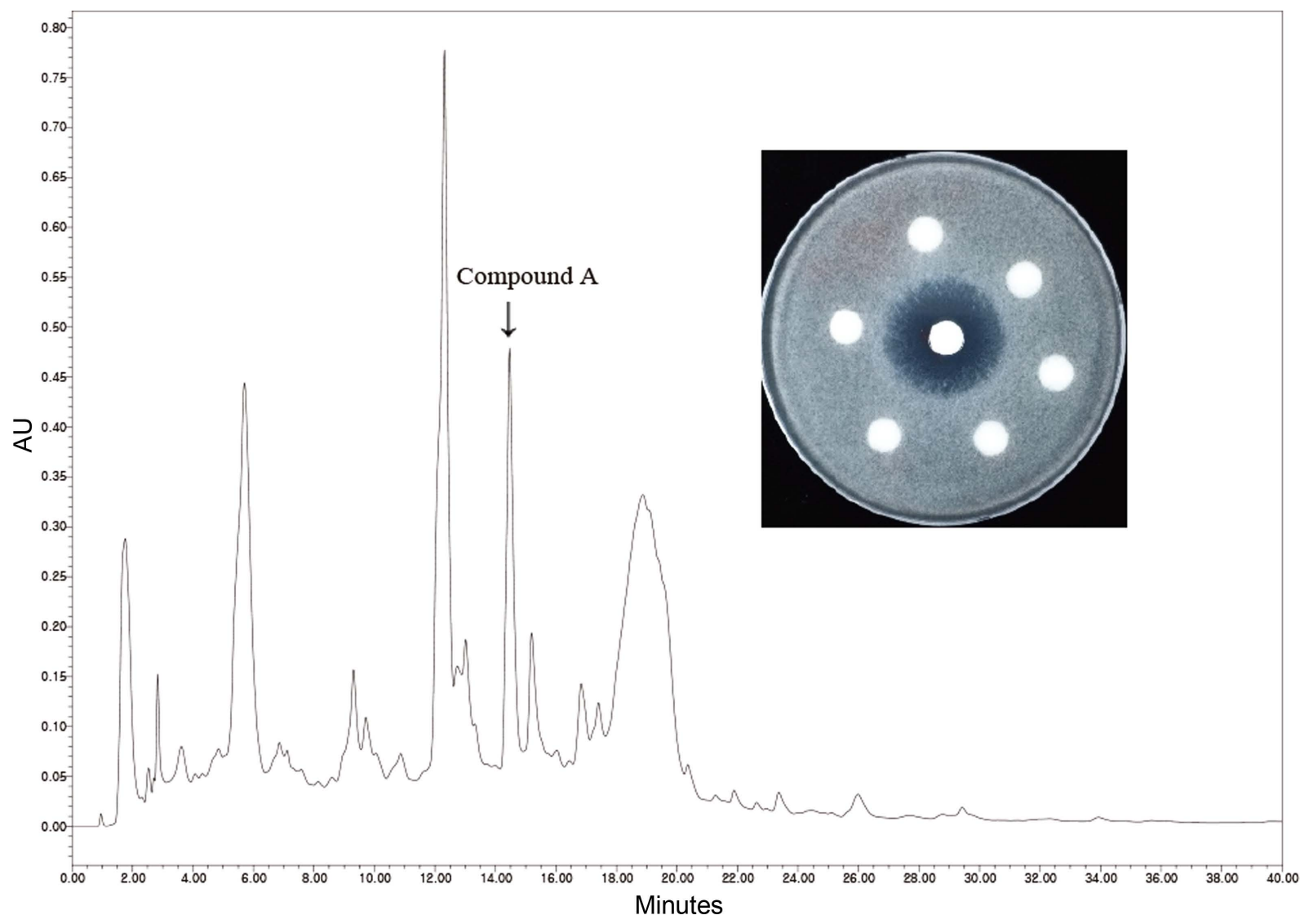

Fig. 1. High-performance liquid chromatogram of compound A.

in Table 1.

Moriniafungin is a derivative of sodarin (an antifungal metabolite possessing a tetracyclic diterpene glycoside structure) that inhibits fungal protein synthesis (Domínguez et al., 1998). Sordarin and their derivatives were originally found by screening protein synthesis inhibitors using a cellfree translational system (Basilio et al., 2006). The mode of action of sordarin was shown to be stabilization of the elongation factor 2 (EF2)-GDP-ribosome complex in fungi (Domínguez et al., 1998; Justice et al., 1998). The specific binding of sordarin to fungal EF2 rather than the EF2 of plants and mammals suggested that sordarin and its derivatives have potential as antifungal drugs with selective toxicity against fungal pathogens in mammalian and plant hosts (Deshmukh et al., 2016).

Moriniafungin contains a 2-hydroxysebacic acid residue linked to the $\mathrm{C}-3^{\prime}$ of the sordarose moiety through a 1,3-dioxolan-4-one ring. Basilio et al. (2006) suggested this kind of modification at $\mathrm{C}-3^{\prime}$ in the sordarose residue can increase the antifungal activity and also broaden the antifungal spectrum compared with sordarin, which could also be applied to other sordarin derivatives, like zofimarin
(Basilio et al., 2006; Daferner et al., 1999; Tanaka et al., 2002). Additionally, C-3' sordarin analogs possessing a side chain with a terminal carboxylic acid are suggested to be involved in binding to EF2, an action thought to be partly responsible for increasing the antifungal spectrum and potency of moriniafungin compared with other C-3' sordarin analogs (Deshmukh et al., 2016).

In vitro antifungal activities of moriniafungin. The MIC values of moriniafungin against phytopathogenic fungi were summarized in Table 2. Among test phytopathogenic fungi, the genus of Colletotrichum and Rhizopus causing anthracnose and soft rot diseases on various fruits and vegetables was most sensitive to moriniafungin. Notably, moriniafungin was effective to inhibit the growth of $R$. oryzae and $R$. stolenifer var. stolenifer at very low concentrations $(0.03-0.13 \mu \mathrm{g} / \mathrm{ml})$. At higher concentration $(1-8 \mu \mathrm{g} /$ $\mathrm{ml}$ ), the growth of $C$. gloeosporioides and C. orbiculare was also completely inhibited by moriniafungin. However, there was no inhibitory effect of moriniafungin against Alternaria, Aspergillus, Botrytis, and Fusarium spp. at the highest concentration tested $(64 \mu \mathrm{g} / \mathrm{ml})$. 


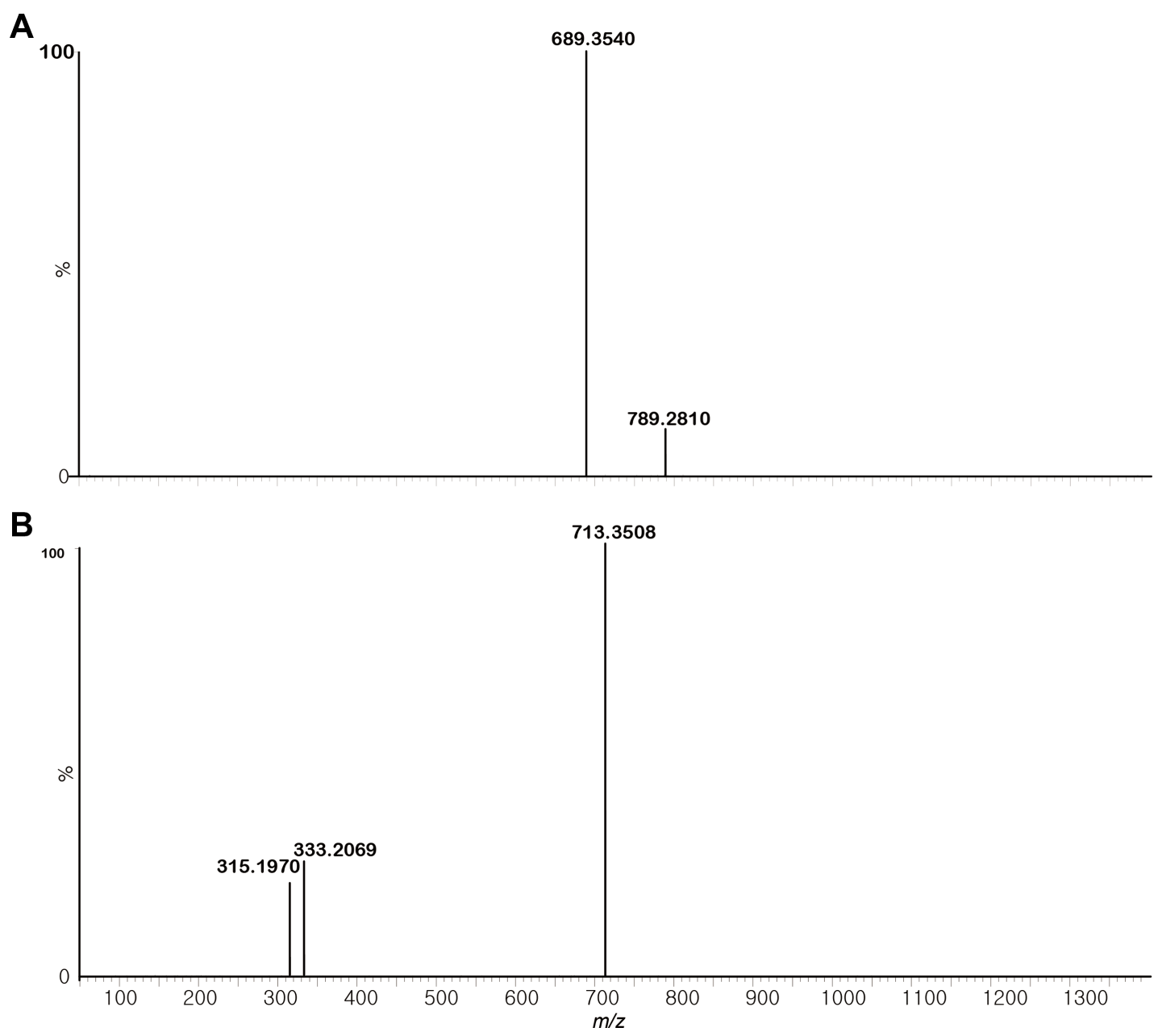

Fig. 2. Mass spectrum of compound A.

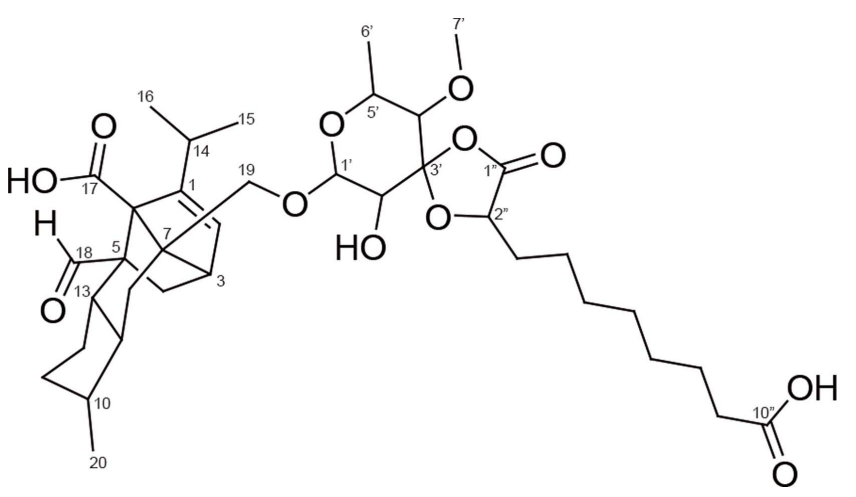

Fig. 3. Structure of compound A.

In determining the MIC values of moriniafungin against phytopathogenic fungi, moriniafungin showed the selective antifungal activity against $R$. oryzae and $R$. stolenifer var. stolenifer with the lowest MIC values of 0.0313 and 0.125 $\mu \mathrm{g} / \mathrm{ml}$, respectively. Similar results have been reported in previous studies on sordarin derivatives. Hydroxysordarin displayed the lowest MIC value of $1 \mu \mathrm{g} / \mathrm{ml}$ against a zygomycete fungus Mucor miehei, while could not inhibited the growth of other filamentous fungi including Alternaria sp. B. cinerea, and Fusarium spp. (Daferner et al., 1999). Similarly, sordarin and GM237354 (a semi-synthetic derivative of sordarin) showed the narrow inhibitory activity against zygomycete fungi including species Absidia, Cunninghamella, Mucor and Zygorhynchus (Daferner et al., 1999; Herreros et al., 1998). Similar to the literature data, in our study, the sordarin analog moriniafungin displayed a narrow antifungal spectrum, with modest antifungal activity against the ascomycetes Colletotrichum spp. but potent activity against the zygomycete fungi Rhizopus spp.

Protective control efficacies of moriniafungin against Rhizopus rot. With the consideration that moriniafungin showed significant inhibitory effects on Rhizopus spp. in the microdilution assay, we examined the disease control 
Table 1. ${ }^{1} \mathrm{H}-\mathrm{NMR}(500 \mathrm{MHz})$ and ${ }^{13} \mathrm{C}-\mathrm{NMR}(125 \mathrm{MHz})$ of moriniafungin measured in chloroform- $d$

\begin{tabular}{|c|c|c|c|c|c|}
\hline Position & Type & $\delta_{\mathrm{e}}(\text { Ref. })^{\mathrm{a}}$ & $\delta_{\mathrm{c}}$ & $\delta_{\mathrm{H}}(\mathrm{J}$ in Hz) (Ref.) & $\delta_{\mathrm{H}}(J$ in $\mathrm{Hz})$ \\
\hline 17 & $\mathrm{COOH}$ & 205.1 & 204.7 & $9.68(\mathrm{~s})$ & $9.73(\mathrm{~s})$ \\
\hline $10^{\prime \prime}$ & $\mathrm{COOH}$ & 178.9 & $* \mathrm{~b}$ & $*$ & $*$ \\
\hline 18 & $\mathrm{CHO}$ & 176.2 & * & * & * \\
\hline $1 "$ & $\mathrm{CO}$ & 172.9 & 172.6 & & \\
\hline 1 & $\mathrm{C}$ & 148.8 & 148.3 & & \\
\hline 2 & $\mathrm{CH}$ & 131.1 & 130.7 & $6.09(\mathrm{dd}, 1.1,3.2)$ & $6.09(\mathrm{~s})$ \\
\hline $3^{\prime}$ & $\mathrm{C}$ & 108.2 & 107.9 & & \\
\hline $1^{\prime}$ & $\mathrm{CH}$ & 98.7 & 98.2 & $4.56(\mathrm{~d}, 0.9)$ & $4.55(\mathrm{~s})$ \\
\hline $4^{\prime}$ & $\mathrm{CH}$ & 83.0 & 82.6 & $3.32(\mathrm{~d}, 9.6)$ & $3.39(\mathrm{~d}, 9.6)$ \\
\hline $2 "$ & $\mathrm{CH}$ & 76.2 & 75.9 & $4.59(\mathrm{dd}, 4.4,7.3)$ & $4.62(\mathrm{dd}, 4.4,7.1)$ \\
\hline 19 & $\mathrm{CH}_{2}$ & 74.9 & 74.7 & $3.72(\mathrm{~d}, 8.7) ; 4.00(\mathrm{~d}, 9.3)$ & $3.75(\mathrm{~d}, 9.5) ; 3.95(\mathrm{~m})$ \\
\hline $2^{\prime}$ & $\mathrm{CH}$ & 74.1 & 73.8 & $3.71(\mathrm{~s})$ & $3.73(\mathrm{~s})$ \\
\hline 6 & $\mathrm{C}$ & 72.9 & 72.4 & & \\
\hline $5^{\prime}$ & $\mathrm{CH}$ & 70.1 & 69.7 & $3.54(\mathrm{dq}, 6.2,9.5)$ & $3.57(\mathrm{~m})$ \\
\hline 7 & $\mathrm{C}$ & 65.9 & 65.5 & & \\
\hline $7^{\prime}$ & $\mathrm{CH}_{3}$ & 62.1 & 62.0 & $3.47(\mathrm{~s})$ & $3.50(\mathrm{~s})$ \\
\hline 5 & $\mathrm{C}$ & 59.2 & 58.8 & & \\
\hline 3 & $\mathrm{CH}$ & 46.9 & 46.2 & $2.70(t, 3.9)$ & $2.74(\mathrm{~s})$ \\
\hline 13 & $\mathrm{CH}$ & 42.1 & 41.7 & 1.99 (ddd, $6.2,11.8,18.2)$ & $2.02(\mathrm{~m})$ \\
\hline 9 & $\mathrm{CH}$ & 41.6 & 41.3 & $1.77(\mathrm{~m})$ & $1.73(\mathrm{~m})$ \\
\hline $9 "$ & $\mathrm{CH}_{2}$ & 34.2 & 28.3 & $2.35(\mathrm{t}, 7.4)$ & 2.34 (br s) \\
\hline $3 "$ & $\mathrm{CH}_{2}$ & 32.5 & 32.2 & $1.83(\mathrm{~m}) ; 1.65(\mathrm{~m})$ & $1.86(\mathrm{~m}) ; 1.65(\mathrm{~m})$ \\
\hline 11 & $\mathrm{CH}_{2}$ & 32.4 & 32.0 & $2.05(\mathrm{~m}) ; 1.22(\mathrm{~m})$ & $2.07(\mathrm{~m}) ; 1.23(\mathrm{~m})$ \\
\hline 10 & $\mathrm{CH}$ & 31.4 & 30.9 & $2.07(\mathrm{~m})$ & $2.07(\mathrm{~m})$ \\
\hline 4 & $\mathrm{CH}_{2}$ & 29.8 & 29.3 & $1.95(\mathrm{~m}) ; 1.25(\mathrm{~m})$ & $1.99(\mathrm{~m}) ; 1.92(\mathrm{~m})$ \\
\hline 8 & $\mathrm{CH}_{2}$ & 29.5 & 29.2 & $1.94(\mathrm{~m}) ; 1.80(\mathrm{~m})$ & $1.99(\mathrm{~m}) ; 1.92(\mathrm{~m})$ \\
\hline $5 "$ & $\mathrm{CH}_{2}$ & 29.3 & 28.9 & $1.26(\mathrm{~m})$ & $1.34(\mathrm{~m})$ \\
\hline $6 "$ & $\mathrm{CH}_{2}$ & 29.2 & 29.0 & $1.26(\mathrm{~m})$ & $1.29(\mathrm{~m})$ \\
\hline $7 "$ & $\mathrm{CH}_{2}$ & 29.1 & 28.8 & $1.26(\mathrm{~m})$ & $1.33(\mathrm{~m})$ \\
\hline 14 & $\mathrm{CH}$ & 28.0 & 27.6 & 2.32 (hept, 6.9) & $2.34(\mathrm{~m})$ \\
\hline 12 & $\mathrm{CH}_{2}$ & 26.6 & 26.3 & $1.86(\mathrm{~m}) ; 0.99(\mathrm{~m})$ & $1.87(\mathrm{~m}) ; 0.99(\mathrm{~m})$ \\
\hline $4 "$ & $\mathrm{CH}_{2}$ & 25.1 & 24.7 & $1.40(\mathrm{~m})$ & $1.64(\mathrm{~m})$ \\
\hline $8^{\prime \prime}$ & $\mathrm{CH}_{2}$ & 25.0 & 24.6 & $1.60(\mathrm{~m})$ & $1.43(\mathrm{~m})$ \\
\hline 16 & $\mathrm{CH}_{3}$ & 22.8 & 22.6 & $0.97(\mathrm{~d}, 6.7)$ & $0.97(\mathrm{~d}, 5.9)$ \\
\hline 15 & $\mathrm{CH}_{3}$ & 21.3 & 21.2 & $1.03(\mathrm{~d}, 6.8)$ & $1.04(\mathrm{~d}, 6.0)$ \\
\hline $6^{\prime}$ & $\mathrm{CH}_{3}$ & 17.7 & 17.5 & $1.32(\mathrm{~d}, 6.2)$ & $1.36(\mathrm{~d}, 6.4)$ \\
\hline 20 & $\mathrm{CH}_{3}$ & 17.5 & 17.4 & $0.81(\mathrm{~d}, 6.9)$ & $0.80(\mathrm{~d}, 6.3)$ \\
\hline
\end{tabular}

NMR, nuclear magnetic resonance.

a Basilio et al. (2006).

b*, not detected.

efficacies of moriniafungin on Rhizopus rot of apple and peach fruits. Four days after inoculation of $R$. oryzae, the typical soft rot symptoms including brownish discoloration, softening, and exudation from wounds were observed on the non-treated apple fruits (Fig. 4A). The mean diameter of the lesions of the inoculated control was $32.00 \pm 2.83$ $\mathrm{mm}$. Moriniafungin $(0.04-5 \mu \mathrm{g} / \mathrm{ml})$ showed no significant effect on reducing apple rot lesions caused by $R$. oryzae (Fig. 4A). However, at higher concentration $(25 \mu \mathrm{g} / \mathrm{ml})$, moriniafungin completely protected apple fruits from the attack of $R$. oryzae (no symptom was observed around the inoculated area). The disease control efficacy of morin- 
Table 2. Minimum inhibitory concentrations (MICs) of moriniafungin against various plant pathogenic fungi

\begin{tabular}{lcc}
\hline & & $\mathrm{MIC}(\mu \mathrm{g} / \mathrm{ml})$ \\
\cline { 2 - 3 } Plant pathogenic fungi & Moriniafungin & Tebuconazole \\
\hline Alternaria brassicicola & $>64$ & $\mathrm{nt}$ \\
Aspergillus oryzae & $>64$ & $\mathrm{nt}$ \\
Botrytis cinerea & $>64$ & $\mathrm{nt}$ \\
Colletotrichum gloeosporioides & 1 & 8 \\
Colletotrichum orbiculare & 8 & 16 \\
Fusarium oxysporum f. sp. lycopersici & $>64$ & $\mathrm{nt}$ \\
Rhizopus oryzae & 0.125 & 2 \\
Rhizopus stolonifer var. stolonifer & 0.03125 & 1 \\
\hline
\end{tabular}

nt, not tested.

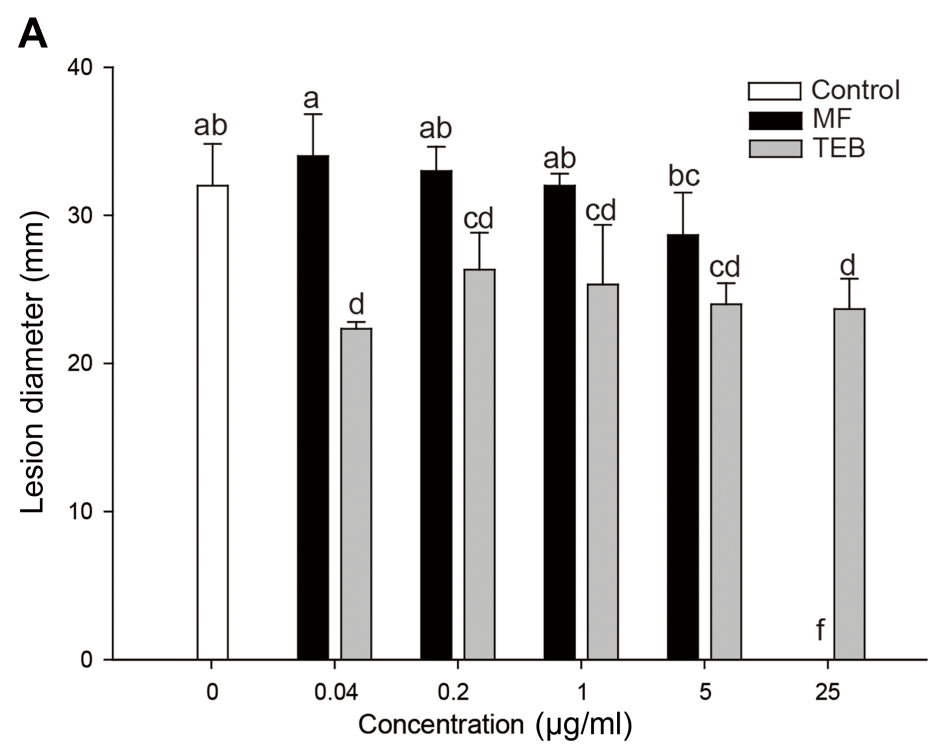

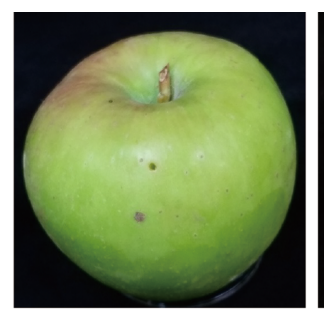

Uninoculated

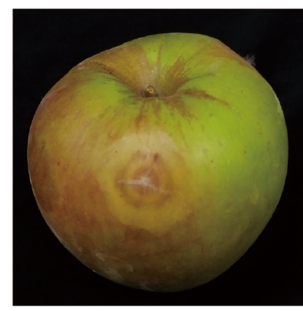

TEB $25 \mu \mathrm{g} / \mathrm{ml}$

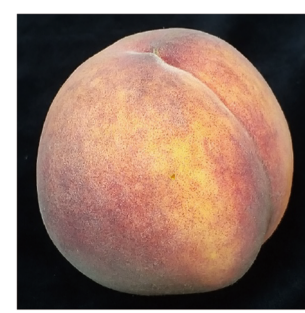

Uninoculated

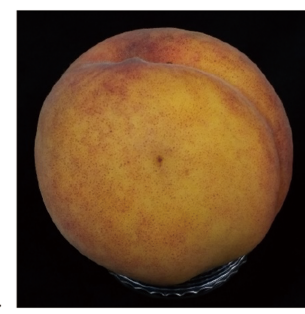

TEB $25 \mu \mathrm{g} / \mathrm{ml}$

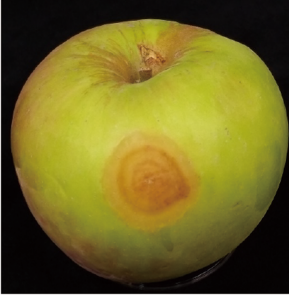

Inoculated control

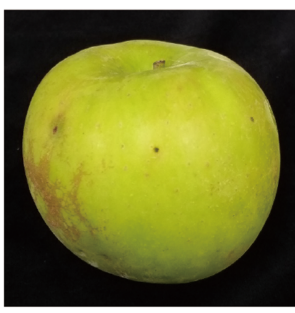

MF $25 \mu \mathrm{g} / \mathrm{ml}$

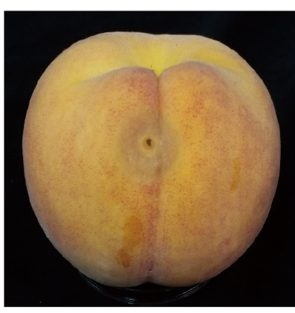

Inoculated control

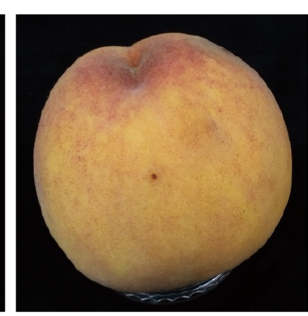

MF $25 \mu \mathrm{g} / \mathrm{ml}$

Concentration $(\mu \mathrm{g} / \mathrm{ml})$

Fig. 4. In vivo control efficacies of treatment with tebuconazole (TEB) and moriniafungin (MF) against Rhizopus rot. The antifungal treatments were performed $1 \mathrm{~h}$ before the inoculation with Rhizopus oryzae on apple fruit (A) and R. stolonifer var. stolonifer on peach fruit (B). The diameter of the lesion of each treatment was measured 4 days after the inoculation. Different lowercase letters on the bars indicate significant differences between treatments by the least significant differences test $(n=3, P<0.05)$. 
iafungin $(25 \mu \mathrm{g} / \mathrm{ml})$ was superior to that of a synthetic fungicide tebuconazole. Even at the highest concentration of tebuconazole $(25 \mu \mathrm{g} / \mathrm{ml})$, apple fruits were discolored, softened, and water-soaked by R. oryzae (Fig. 4A).

Furthermore, moriniafungin effectively controlled the Rhizopus rot development of peach fruits caused by $R$. stolonifer var. stolonifer (Fig. 4B). The mean diameter of lesions on the inoculated control was $20.67 \pm 3.09 \mathrm{~mm}$. At all applied concentrations, moriniafungin and tebuconazole reduced rot disease development significantly compared with the non-treated control. At concentrations of 0.04$5 \mu \mathrm{g} / \mathrm{ml}$, moriniafungin significantly reduced the lesion diameter by $56.5-80 \%$, compared with the non-treated control. When treated with moriniafungin $(25 \mu \mathrm{g} / \mathrm{ml})$, more than $90 \%$ reduction in diameter of lesions was observed. The inhibitory activity of moriniafungin against infection and colonization of $R$. stolenifer var. stolenifer on peach fruits was comparable to that of a synthetic fungicide tebuconazole (Fig. 4B).

Considering the potent inhibitory activity of moriniafungin against Rhizopus spp. in vitro, moriniafungin was examined for controlling Rhizopus rot of apple and peach fruits and thus evidently reduced the development of discolored, softened, and water-soaked lesions on fruits (Fig. 4). The in vivo antifungal effect of moriniafungin was comparable to that of tebuconazole, an effective fungicide to control postharvest Rhizopus rot of wounded peach fruits (Northover and Zhou, 2002).

For several decades, fungal metabolites have been investigated as control agents of postharvest diseases. 6-Pentyl2-pyrone produced by Trichoderma spp. was reported to be effective in reducing the incidence of $B$. cinerea storage rots in kiwifruit (Bonnarme et al., 1997; Poole et al., 1998). 6-Pentyl-2-pyrone is a naturally-occurring compound also found in ripening peach and nectarine, which makes it acceptable as a food flavoring additive or postharvest treatment (Horvat et al., 1990). Fusapyrone and deoxyfusapyrone, identified from the culture of Fusarium semitectum, showed inhibitory activity against $B$. cinerea on grapes at $100 \mu \mathrm{g} / \mathrm{ml}$ and displayed no phytotoxicity and low toxicity in mammals, which makes them potential agents for postharvest disease control (Altomare et al., 2000).

This study revealed that moriniafungin, isolated from the culture extract of $S$. rostrata strain F3736, could inhibit the growth of several species of plant pathogenic fungi. Especially, the MIC of moriniafungin against Rhizopus spp. was an order of magnitude lower than that of tebuconazole, the commercial fungicide used as the positive control. Moriniafungin reduced the lesion development on apple and peach fruits significantly compared with the non-treated control, which was comparable to the treatment of tebuconazole at the same concentrations. In this study, the sordarin derivative moriniafungin, as a specific inhibitor of fungal EF2, was suggested as a potential control agent of postharvest diseases caused by Rhizopus species.

\section{Conflicts of Interest}

No potential conflict of interest relevant to this article was reported.

\section{Acknowledgments}

This research was supported by the Korea Institute of Planning and Evaluation for Technology of Food, Agriculture, Forestry and Fisheries (316011-05), Republic of Korea.

\section{Electronic Supplementary Material}

Supplementary materials are available at The Plant Pathology Journal website (http://www.ppjonline.org/).

\section{References}

Altomare, C., Perrone, G., Zonno, M. C., Evidente, A., Pengue, R., Fanti, F. and Polonelli, L. 2000. Biological characterization of fusapyrone and deoxyfusapyrone, two bioactive secondary metabolites of Fusarium semitectum. J. Nat. Prod. 63:11311135 .

Amadioha, A. C. 2001. Fungitoxic effects of some leaf extracts against Rhizopus oryzae causing tuber rot of potato. Arch. Phytopathol. Plant Prot. 33:499-507.

Anke, T., Oberwinkler, F., Steglich, W. and Schramm, G. 1977. The strobilurins: new antifungal antibiotics from the basidiomycete Strobilurus tenacellus. J. Antibiot. 30:806-810.

Bartlett, D. W., Clough, J. M., Godwin, J. R., Hall, A. A., Hamer, M. and Parr-Dobrzanski, B. 2002. The strobilurin fungicides. Pest Manag. Sci. 58:649-662.

Basilio, A., Justice, M., Harris, G., Bills, G., Collado, J., de la Cruz, M., Diez, M. T., Hernandez, P., Liberator, P., Nielsen Kahn, J., Pelaez, F, Platas, G., Schmatz, D., Shastry, M., Tormo, J. R., Andersen, G. R. and Vicente, F. 2006. The discovery of moriniafungin, a novel sordarin derivative produced by Morinia pestalozzioides. Bioorg. Med. Chem. 14:560-566.

Batta, Y. A. 2007. Control of postharvest diseases of fruit with an invert emulsion formulation of Trichoderma harzianum Rifai. Postharvest Biol. Technol. 43:143-150.

Bautista-Baños, S., Bosquez-Molina, E. and Barrera-Necha, L. L. 2014. Rhizopus stolonifer (soft rot). In: Postharvest decay: control strategies, ed. By S. Banos, pp. 1-44. Elsevier, London, UK.

Bonnarme, P., Djian, A., Latrasse, A., Féron, G., Ginies, C., Du- 
rand, A. and Le Quéré, J.-L. 1997. Production of 6-pentyl- $\alpha$ pyrone by Trichoderma sp. from vegetable oils. J. Biotechnol. 56:143-150.

Clough, J. M., Anthony, V. M., de Fraine, P. J., Fraser, T. E. M., Godfrey, C. R. A., Godwin, J. R. and Youle, D. 1995. The synthesis of fungicidal $\beta$-methoxyacrylates. In: Proceedings of the Eighth International Congress of Pesticide Chemistry, eds. by N. N. Ragsdale, P. C. Kearney and J. R. Plimmer, pp. 59-73. American Chemical Society, Washington, DC, USA.

Daferner, M., Mensch, S., Anke, T. and Sterner, O. 1999. Hypoxysordarin, a new sordarin derivative from Hypoxylon croceum. Z. Naturforsch. C J. Biosci. C 54:474-480.

Dennis, C. 1983. Post-harvest pathology of fruits and vegetables. Academic Press, London, UK. 264 pp.

Deshmukh, S. K., Misra, J. K., Tewari, J. P. and Papp, T. 2016. Fungi: applications and management strategies. CRC Press, Boca Raton, FL, USA. 496 pp.

Domínguez, J. M., Kelly, V. A., Kinsman, O. S., Marriott, M. S., de las Heras, F. G. and Martín, J. J. 1998. Sordarins: a new class of antifungals with selective inhibition of the protein synthesis elongation cycle in yeasts. Antimicrob. Agents Chemother. 42:2274-2278.

El-Katatny, M. H. and Emam, A. S. 2020. Control of postharvest tomato rot by spore suspension and antifungal metabolites of Trichoderma harzianum. J. Microbiol. Biotechnol. Food Sci. 1:1505-1528.

Espinel-Ingroff, A., Fothergill, A., Ghannoum, M., Manavathu, E., Ostrosky-Zeichner, L., Pfaller, M., Rinaldi, M., Schell, W. and Walsh, T. 2005. Quality control and reference guidelines for CLSI broth microdilution susceptibility method (M38-A document) for amphotericin B, itraconazole, posaconazole, and voriconazole. J. Clin. Microbiol. 43:5243-5246.

Harman, G. E., Howell, C. R., Viterbo, A., Chet, I. and Lorito, M. 2004. Trichoderma species: opportunistic, avirulent plant symbionts. Nat. Rev. Microbiol. 2:43-56.

Herreros, E., Martinez, C. M., Almela, M. J., Marriott, M. S., De Las Heras, F. G. and Gargallo-Viola, D. 1998. Sordarins: in vitro activities of new antifungal derivatives against pathogenic yeasts, Pneumocystis carinii, and filamentous fungi. Antimicrob. Agents Chemother. 42:2863-2869.

Horvat, R. J., Chapman, G. W. Jr., Robertson, J. A., Meredith, F. I., Scorza, R., Callahan, A. M. and Morgens, P. 1990. Comparison of the volatile compounds from several commercial peach cultivars. J. Agric. Food Chem. 38:234-237.

Justice, M. C., Hsu, M.-J., Tse, B., Ku, T., Balkovec, J., Schmatz, D. and Nielsen, J. 1998. Elongation factor 2 as a novel target for selective inhibition of fungal protein synthesis. J. Biol. Chem. 273:3148-3151.

Kim, B. S. and Hwang, B. K. 2007. Microbial fungicides in the control of plant diseases. J. Phytopathol. 155:641-653.

Liu, S.-Y., Lo, C.-T., Chen, C., Liu, M.-Y., Chen, J.-H. and Peng, K.-C. 2007. Efficient isolation of anthraquinone-derivatives from Trichoderma harzianum ETS 323. J. Biochem. Biophys.
Methods 70:391-395.

Northover, J. and Zhou, T. 2002. Control of rhizopus rot of peaches with postharvest treatments of tebuconazole, fludioxonil, and Pseudomonas syringae. Can. J. Plant Pathol. 24:144153.

Pascale, A., Vinale, F., Manganiello, G., Nigro, M., Lanzuise, S., Ruocco, M., Marra, R., Lombardi, N., Woo, S. L. and Lorito, M. 2017. Trichoderma and its secondary metabolites improve yield and quality of grapes. Crop Prot. 92:176-181.

Paster, N. and Bullerman, L. B. 1988. Mould spoilage and mycotoxin formation in grains as controlled by physical means. Int. J. Food Microbiol. 7:257-265.

Poole, P. R., Ward, B. G. and Whitaker, G. 1998. The effects of topical treatments with 6-pentyl-2-pyrone and structural analogues on stem end postharvest rots in kiwifruit due to Botrytis cinerea. J. Sci. Food Agric. 77:81-86.

Porter, N. 1985. Physicochemical and biophysical panel symposium biologically active secondary metabolites. Pestic. Sci. 16:422-427.

Qing, F. and Shiping, T. 2000. Postharvest biological control of Rhizopus rot of nectarine fruits by Pichia membranefaciens. Plant Dis. 84:1212-1216.

Roberts, R. G. 1990. Postharvest biological control of gray mold of apple by Cryptococcus laurentii. Phytopathology 80:526530.

Salem, E. A., Youssef, K. and Sanzani, S. M. 2016. Evaluation of alternative means to control postharvest Rhizopus rot of peaches. Sci. Hortic. 198:86-90.

Scarselletti, R. and Faull, J. L. 1994. In vitro activity of 6-pentyl$\alpha$-pyrone, a metabolite of Trichoderma harzianum, in the inhibition of Rhizoctonia solani and Fusarium oxysporum $\mathrm{f}$. sp. lycopersici. Mycol. Res. 98:1207-1209.

Tanaka, M., Moriguchi, T., Kizuka, M., Ono, Y., Miyakoshi, S.I. and Ogita, T. 2002. Microbial hydroxylation of zofimarin, a sordarin-related antibiotic. J. Antibiot. 55:437-441.

Tang, B., Pan, H., Tang, W., Zhang, Q., Ding, L. and Zhang, F. 2012. Fermentation and purification of cellulase from a novel strain Rhizopus stolonifer var. reflexus TP-02. Biomass Bioenergy 36:366-372.

Tripathi, P. and Dubey, N. K. 2004. Exploitation of natural products as an alternative strategy to control postharvest fungal rotting of fruit and vegetables. Postharvest Biol. Technol. 32:235-245.

Usall, J., Torres, R. and Teixidó, N. 2016. Biological control of postharvest diseases on fruit: a suitable alternative? Curr. Opin. Food Sci. 11:51-55.

Wisniewski, M. E. and Wilson, C. L. 1992. Biological control of postharvest diseases of fruits and vegetables: recent advances. HortScience 27:94-98.

Zhang, H., Godana, E. A., Sui, Y., Yang, Q., Zhang, X. and Zhao, L. 2020. Biological control as an alternative to synthetic fungicides for the management of grey and blue mould diseases of table grapes: a review. Crit. Rev. Microbiol. 46:450-462. 